\title{
Promosi Kesehatan Dengan Metode Focus Group Discussion Dapat Mempengaruhi Pengetahuan Tentang Diabetes Melitus
}

\section{Health Promotion Using The Focus Group Discussion Method Can Affect Knowledge About Diabetes Melitus}

\author{
Satrio Kusnanda Murdiqi Kusaeri ${ }^{1(\mathrm{CA})}$, Nutrisia Nu’im Haiya ${ }^{2}$, Iwan Ardian ${ }^{3}$ \\ ${ }^{1(\mathrm{CA})}$ Program Studi S1 Keperawatan, Fakultas Ilmu Keperawatan, Universitas Islam Sultan Agung \\ Semarang; satriokusnandamurdiqi@gmail.com (Corresponding Author) \\ ${ }^{2}$ Fakultas Ilmu Keperawatan, Universitas Islam Sultan Agung Semarang \\ ${ }^{3}$ Fakultas Ilmu Keperawatan, Universitas Islam Sultan Agung Semarang
}

\begin{abstract}
Diabetes mellitus is a challenge that is lowered by hyperglycemia which causes weight loss, blood sugar that can overcome the damage to body organs, such as eye blindness, glomerulosclerosis neuropathy, blood, and stroke, cardiovascular risk, and diabetes foot disease, the use of promotion of FGD methods to increase knowledge in this research to see the importance of knowledge in diabetes mellitus at the Bangetayu Public Health Center in Semarang. This type of quasi-experimental research (experimental quast) with a control group design with pre-test-post-test. consecutive sampling techniques, consecutive sampling (sequential), a total sample of 55 respondents, as many as 28 for the meeting group and as many as 27 for the control group. Based on the results of an analysis of health promotion using the Focus Group Discussion method with community knowledge about diabetes mellitus. Relating to health promotion by the Focus Group Discussion method on public knowledge about diabetes mellitus.
\end{abstract}

Keywords: Focus Group Discussion method, Diabetes knowledge mellitus health Promotion

\begin{abstract}
ABSTRAK
Diabetes Melitus merupakan hilangnya toleransi karbohidrat dan hiperglikemia yang menimbulkan penurunan berat badan, guladarah yang tinggi bisa mengakibatkan rusaknya organ-organ tubuh,seperti kebutaan mata, glomerulosklerosis neuropati, ginjal, dan stroke, gagal jantung pada kardiovaskular, serta penyakit kaki diabetic, penggunaan promosi kesehatan metode FGD untuk meningkatkan pengetahuan pada penelitian ini bertujuan untuk melihat pengaruh pengetahuan pada diabetes melitus di Puskesmas Bangetayu Semarang. Jenis penelitian eksperimen semu (quast experimental) with control group design dengan pre - test - post - test. teknik consecutive sampling, consecutive sampling (berurutan), total sempel ada 55 responden, sebanyak 28 untuk kelompok perlakuan dan sebanyak 27 untuk kelompok kontrol. Berdasarkan hasil analisis terdapat pengaruh promosi kesehatan dengan metode Focus Group Discussion terhadap pengetahuan masyarakat tentang diabetes melitus. Terdapat pengaruh promosi kesehatan dengan metode Focus Group Discussion terhadap pengetahuan masyarakat tentang diabetes mellitus.
\end{abstract}

Kata Kunci : Metode Focus Group Discussion, pengetahuan Diabetes Melitus Promosi kesehatan

\section{PENDAHULUAN}

Diabetes Melitus adalah kerusakan pada metabolisme bisa disebabkan oleh faktor klinis atau genetik dengan hilangnya karbohidrat dan hiperglikemia yang bisa ditandai dengan gejala fisik berupa 
berat badan turun, poliuri, kelelahan.(Dagogo, 2016). Gula darah yang tinggi dapat mengakibatkan kerusakan pada organ-organ tubuh, seperti gangguan penglihatan, gagal ginjal, neuropati dan stroke pada saraf, gagal jantung pada kardiovaskular, serta sakit kaki diabetik (Boulton, 2011).

Di dunia penderita diabetes mellitus semakin meningkat dari 108 juta di tahun 1980 mencapai 422 juta pada tahun 2014 (World Health Organization (WHO) 2016). Indonesia mempunyai 7 juta orang penderita diabetes melitus, di Indonesia sebagai negara ke 9 dengan diabetes melitus terbanyak di tahun 2010 dan prediksi bisa menjadi peringkat ke 6 pada tahun 2030 (Shaw, Sicree \& Zimmet, 2010 dalam Niswah: Chinnawong \& Manasurakam, 2014). Diabetes melitus saat ini bisa jadi salah satu penyebab kematian terbesar di Indonesia. Diperoleh dari data penyebab kematian akibat diabetes melitus pada kelompok usia 45-54 tahun di kota menunjukan peringkat ke-2 yaitu sebanyak 14,7\%. Sedangkan di desa diabetes melitus menunjukan peringkat ke 6 yaitu 5,8\% ( Riskesdas,2007 dalam RI Kemenkes, 2009).

Apabila penyakit diabetes melitus tidak segera ditangani dapat menimbulkan beberapa komplikasi diantaranya adalah meningkatnya resiko penyakit jantung dan stroke, kerusakan saraf di kaki yang dapat menimbulkan ulkus diabetik infeksi bahkan sampai di amputasi, retinopati diabetikum akibat kerusakan pembuluh darah kecil di retina,resiko kematian 2 kali lipat dibanding bukan penderita diabetes melitus (RI Kemenkes, 2014).

Diabetes melitus merupakan salah satu mudah cara perawatannya. Beberapa diantaranya adalah olahraga teratur, diet rendah gula, mengonsumsi obat oral dan suntik insulin. Jika semua cara tersebut dilakukan, maka kadar gula darah dapat terkendali (Putra dan Berawi, 2015). Namun berdasarkan hasil riskesdas (2013) penduduk Indonesia memiliki kegiatan fisik kurang aktif umumnya sebanyak $26,1 \%$. Didapatkan sebanyak 22 provinsi di Indonesia yang kegiatan fisiknya tergolong kurang efektif diatas ratarata Indonesia, dan 5 provinsi tertinggi dengan fisik yang kurang aktif yaitu provinsi DKI Jakarta (44,2\%), Papua (38,9\%), Papua Barat (37,8\%), Sulawesi Tenggara dan Aceh (masing-masing 37,2\%) Maka dari itu seringkali orang yang menderita diabetes melitus tidak dapat mengontrol dengan baik kadar gula darahnya agar tetap normal.

Menurut Waspadji, 2010 untuk meningkatkan kemampuan yang cukup tentang perawatan diabetes melitus, perlu diberikan pengetahuan diabetes melitus, dan dilakukan pengetahuan tentang diabetes melitus. Dari pengetahuan diabetes melitus dapat membantu mengatasi diabetes selama hidupnya sehingga bisa mengerti bagaimana harus merubah perilakunya dan mengapa hal itu diperlukan.

Dari penelitian pengetahuan diabetes melitus di Indonesia menunjukan rendah dalam pengetahuan, diantaranya di RSUP dr. Djamil Padang tahun 2015 telah dilakukan penelitian menunjukan pasien Diabetes melitus tipe II masih memiliki pengetahuan yang kurang terkait lima pilar penatalaksanaan Diabetes Melitus tipe II (Kemenkes,2015). Hasil ini sejalan dengan Rumah sakit Pusat Angkatan Darat Gatot Soebroto Jakarta Pusat yang telah dilakukan penelitian menunjukan tingkat pengetahuan pasien Diabetes Melitus tentang diet Diabetes melitus dan latian jasmani dinilai sedang,dan tingkat pengetahuan pasien Diabetes melitus tentang monitoring kadar gula darah dan obat-obat Diabetes Melitus di nilai rendah (Gulton, 2012).

Melihat masih kurangnya pengetahuan tentang diabetes melitus. Maka pendidikan kesehatan sangatlah penting untuk dapat meningkatkan pengetahuan (Juwitaningtyas, 2014). Komplikasi dari 
Diabetes melitus dapat dikurangi dengan mengendalikan 4 pilar penatalaksanaan yaitu edukasi, diet, aktifitas fisik, pengobatan dan kepatuhan (Putri, 2013). Dalam 4 pilar penatalaksanaan Diabetes melitus, memberikan pengetahuan untuk peranan utama yang menjadikan dasar pengetahuan (Aljoudi \& Taha, 2009). Metode yang efektif digunakan untuk edukasi Diabetes melitus secara garis besar yaitu metode Didaktif dan Sokratik (Maulana, 2009). Salah satu metode yang efektif digunakan adalah FGD (Focus Group Discussion).

Berdasarkan hasil penelitian yang dilakukan oleh Julita supita di Manado terdapat peningkatan sebelum diberikan FGD adalah 24,06 dan sesudah diberikan adalah 40,60 (Julita, 2018). Dan hasil survey pendahuluan di Puskesmas Bangetayu Semarang didapatkan data dari 6 responden klien diabetes, terdapat 2 diantaranya bisa menjelaskan tentang penyakit DM dan 4 diantaranya kurang memahami tentang penyakit Diabetes Melitus. Maka dari itu, peneliti tertarik untuk melihat adanya pengaruh promosi kesehatan dengan metode FGD terhadap pengetahuan penyakit Diabetes Melitus.

\section{METODE}

Penelitian ini adalah penelitian kuantitatif. dimana penelitian ini mengungkapkan adanya sebab ataupun akibat dengan cara melibatkan kelompok control atau kelompok perlakuan. Penelitian ini menggunakan design Quasi experiment with control group pre test post test. Responden dalam penelitian ini adalahpada masyarakat yang mengikuti kegiatan prolanis di puskesmas Bangetayu dengan kategori usia 36-70 tahun. Penelitian ini di laksanakan pada bulan November, penelitian ini mengambil sample 55. Teknik pengambilannya menggunakan teknik consecutive sampling. Instrument yang digunakan dalam penelitian ini adalah lembar kuesioner dengan jumlah pertanyaan DKQ-24 (Diabetes Knowladge Questionnaire).

\section{HASIL DAN PEMBAHASAN}

1. Pengetahuan Pre test (Sesudah perlakuan)

Tabel 1 Distribusi frekuensi responden berdasarkan pengetahuan sebelum diberikan metode FGD (Focus Group Discussion) kelompok perlakuan dan kontrol di Puskesmas Bangetayu Semarang bulan November $2019(\mathrm{n}=55)$

\begin{tabular}{llcccc}
\hline \multirow{2}{*}{ No } & \multirow{2}{*}{ Pengetahuan } & \multicolumn{2}{c}{ Perlakuan } & \multicolumn{2}{c}{ Kontrol } \\
\cline { 3 - 6 } & & $\mathrm{n}$ & $\%$ & $\mathrm{n}$ & $\%$ \\
\hline 1 & Rendah & 5 & 17,9 & 4 & 14,8 \\
2 & Sedang & 23 & 82,1 & 23 & 85,2 \\
\hline
\end{tabular}

Tabel 1 menggambarkan penegetahuan sebelum diberikan promosi kesehatan dengan metode FGD (Focus Group Discussion) pada kelompok perlakuan terbanyak yaitu kategori sedang dengan jumlah 23 responden $(82,1 \%)$. Hasil ini sejalan dengan kelompok kontrol pengetahuan sebelum diberikan promosi kesehatan dengan metode FGD (Focus Group Discussion) terbanyak yaitu kategori sedang dengan jumlah 23 responden $(85,2 \%)$. 
2. Pengetahuan Post test (Sesudah perlakuan)

Tabel 2. Distribusi frekuensi responden pada pengetahuan sesudah diberikan promosi kesehatan dengan metode FGD (Focus Group Discussion) kelompok perlakuan dan kontrol di Puskesmas Bangetayu Semarang bulan November $2019(\mathrm{n}=55)$

\begin{tabular}{|c|c|c|c|c|c|}
\hline \multirow{2}{*}{ No } & \multirow{2}{*}{ Pengetahuan } & \multicolumn{2}{|c|}{ Perlakuan } & \multicolumn{2}{|c|}{ Kontrol } \\
\hline & & $\mathrm{N}$ & $\%$ & $\mathrm{n}$ & $\%$ \\
\hline 1 & Sedang & 1 & 3,6 & 12 & 44,4 \\
\hline 2 & Tinggi & 27 & 96,1 & 15 & 55,6 \\
\hline & Jumlah & 28 & 100,0 & 27 & 100,0 \\
\hline
\end{tabular}

Tabel 2 menggambarkan pengetahuan sesudah diberikan promosi kesehatan dengan metode FGD (Focus Group Discussion) pada kelompok perlakuan terbanyak yaitu kategori tinggi dengan jumlah 27 responden (96\%). Hasil ini sejalan dengan kelompok kontrol pengetahuan sesudah diberikan promosi kesehatan dengan metode FGD (Focus Group Discussion) terbanyak yaitu kategori tinggi dengan jumlah 15 responden $(55,6 \%)$. Berdasarkan penelitian dan penelitian sebelumnya yang memiliki keterkaitan, peneliti berasumsi bahwa pengetahuan sebelum diberikan promosi kesehatan lebih rendah dan setelah diberikan promosi kesehatan lebih tinggi.

3. Pengaruh penilitian promosi kesehatan dengan metode Fcocus Group Discussion

Tabel 3 Analisis perbedaan sebelum dan sesudah diberikan promosi kesehatan dengan diberikan metode FGD (Focus Group Discussion) kelompok perlakuan dan kontrol di Puskesmas Bangetayu Semarang bulan November $2019(\mathrm{n}=55)$

\begin{tabular}{lrrrr}
\hline & \multicolumn{1}{c}{$\begin{array}{c}\text { Pre test } \\
\text { perlakuan }\end{array}$} & $\begin{array}{l}\text { Pre test } \\
\text { control }\end{array}$ & $\begin{array}{c}\text { Post test } \\
\text { Perlakuan }\end{array}$ & \multicolumn{2}{c}{$\begin{array}{c}\text { Post test } \\
\text { kontrol }\end{array}$} \\
\hline Nilai chi square & 11,571 & 24,143 & 13,370 &, 333 \\
Df & 1 & 1 & 1 & 1 \\
P - value &, 001 &, 000 &, 000 &, 564 \\
\hline
\end{tabular}

Tabel 3 menjelaskan hasil analisis pengaruh promosi kesehatan dengan metode FGD (Focus Group Discussion) terhadap pengetahuan tentang diabetes melitus diperoleh hasil bahwa nilai chi square nya pada kelompok perlakuan yaitu 11,571 dengan nilai $p$ - value 0,001 pada saat pre test sedangkan pada saat post test $p$-value 0,000 dan chi square nya 13,370 sedangkan pada kelompok kontrol didapatkan hasil chi square nya yaitu 24,143 dengan $p$ - value 0,000 pada saat pre test sedangkan pada saat post test $p$-value 0,564 dan chi square nya 0,333 . Hasil uji ini menunjukkan bahwa adanya promosi kesehatan dengan diberikan metode FGD (Focus Group Discussion) kelompok perlakuan dan kontrol di Puskesmas Bangetayu Semarang, hal ini ditunjukan karena $p-$ value $<0,1$ sehingga Ho di tolak dan Ha diterima.

\section{PEMBAHASAN}

Hasil uji statistik Chi-square setelah diberikan promosi kesehatan dengan metode FGD (Focus Group Discussion) pada kelompok perlakuan di dapatkan nilai $p$ - value 0,000 ( $p$-value $<0,1)$ yang artinya ada pengaruh promosi kesehatan denga metode FGD (Focus Group Discussion) terhadap 
pengetahuan diabete melitus. Sedangkan pada kelompok kontrol didapatkan hasil $p-$ value 0,564 ( $p$ value $<0,1$ ). Pada hasil analisa juga diperoleh nilai Chi - square pada kelompok perlakuan setelah diberikan Promosi kesehatan yaitu 13,370 sedangkan pada kelompok kontrol yaitu 0,333. Ini artinya ada pengaruh nya juga. Kesimpulan ini diambil berdasarkan Chi - square. Jika nilai Chi - square >Chisquare tabel $(2,706)$ untuk $p$-value 0,1 maka Ho ditolak dan Ha diterima.

Berdasarkan Hasil penelitian Putria Carolina (2018), terdapat ada perubahan pada tingkat pengetahuan sebelum (pre) dan sesudah (post) dilakukan pendidikan kesehatan yang bisa dilihat dengan melihat hasil uji statistik diperoleh hasil signifikansi ( $p$ - value) adalah 0,000. bisa disimpulkan tingkat pengetahuan ada perbedaan yang sangat signifika, Hal itu sejalan dengan penelitian Gresty Massi Vandri Kallo (2018), Hasil Uji analisis pada tingkat pengetahuan sebelum dan sesudah edukasi dengan motede video dan FGD pada kelompok intervensi menggunakan uji paired t-test dengan tingkat kesalahan alpha 0,05. menunjukan nilai mean sebelum diberikan edukasi dengan video dan FGD adalah 24.06 dan sesudah diberikan edukasi adalah 40.60 dengan standar deviasi sebelum adalah 5.873 dan sesudah 0.828 dengan nilai p sebelum edukasi dengan metode video dan FGD adalah 0.000, dan sesudah edukasi adalah 0.000, yang menunjukan terdapat perbedaan sebelum dan sesudah edukasi yang signifikan.

Berdasarkan hasil analisa peneliti, bahwa terdapat keterkaitan, berasumsi bahwa promosi kesehatan metode FGD (Focus Group Discussion) tentang diabetes melitus yang diberikan kepada kelompok perlakuan memiliki peningkatan yang signifikan, namun pada kelompok kontrol yang tidak diberikan perlakuan hanya diberikan ceramah juga mengalami peningkatan tetapi tidak signifikan, hal ini bisa dilihat dari nilai $C h i$ - square yang mana kelompok perlakuan lebih tinggi dari pada kelompok kontrol.

\section{KESIMPULAN}

Ada pengaruh pengetahuan sebelum dan sesudah diberikan promosi kesehatan dengan metode Focus Group Discussion terhadap pengetahuan masyarakat terhadap diabetes melitus.

\section{DAFTAR PUSTAKA}

Alimul Hidayat, Aziz. 2009. Metodologi Penelitian Keperawatan dan Etika penelitian. Jakarta: Salemba Medika.

Brownle, 'Michaeel., Loyd P. Aielo., Mark E. Coper',, Aoron I. Vink., Richrd W. Nesto., and Andreew J.M. Boulton. 2011. Compliications of diabetes melitus., in Mellmed, Shlmoo., Keneth S. Polonky., P. Red Lasen., Hery M. Kroneberg. Wiliams Textbook of Endoocrinology.12th ed. Philadelpia: Elsevier.

Indrizal, E., 2014, ;Diskusi Kelompok Terarah Focus Group Discussion (prinsip-prinsip dan Langkah Pelaksanaan Lapangan), Jurnal Antropologi", Vol 16. No 1.

Notoatmodjo, S. (2010). Promosi Kesehatan Dan Perilaku Kesehatan .Jakarta : Rineka Cipta. (2012). Metodologi Penelitian Kesehatan.Jakarta : Rineka Cipta. (2012). Promosi Kesehatan Dan Perilaku Kesehatan .Jakarta : Rineka Cipta. 
Nursalam. (2017). Metodologi Penelitian Ilmu Keperawatan. Jakarta: Selemba Medika.

Nursalam. (2014). Metodologi Penelitian Ilmu Keperawatan. Jakarta: Selemba Medika.

Putra, I. W., \& Bewari, K. N. (2015). Empat Pilar Penatalaksanaan Pasien Diabetes Melitus Tipe 2. Jurnal Kesehatan , 8-12.

Riskesdas, R. K. (2013). Pedoman Pewawancara Petugas Pengumpul Data.Jakarta: Badan Litbangkes dan Depkes RI.

Sugiyono. 2011. Metode Penelitian Kuantitatif, Kualitatif dan R\&D. Bandung: Afabeta. 